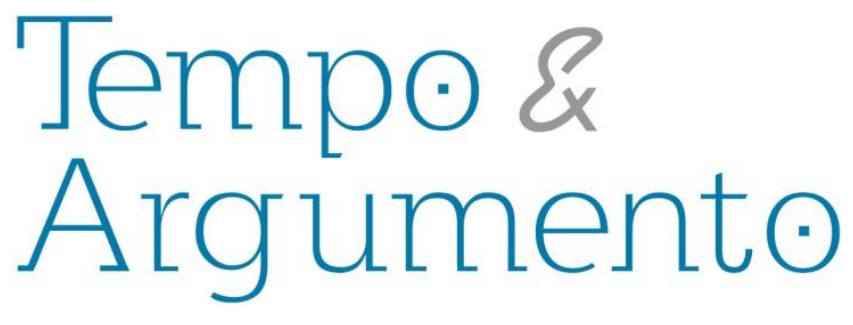

\title{
"A miséria me obriga a escrever ao senhor": a escrita de si em cartas de alemães ao prefeito de Blumenau-SC (1946-1948)
}

\begin{abstract}
Resumo
O artigo analisa a "escrita de si" em cartas-pedido (Bittbriefe) enviadas entre 1946 e 1948 da Alemanha à prefeitura municipal de Blumenau-SC, Brasil. Os pedidos de donativos ou informações eram acompanhados de justificativas fundamentadas nas condições de vida e/ou histórias de vida dos remetentes e a situação do país. Analiso as estratégias retóricas empregadas na interlocução com o destinatário, o imaginário existente acerca da cidade, a mobilização da identidade étnico-nacional e a configuração de narrativas trágicas da guerra e do pós-guerra.
\end{abstract}

Palavras-chave: Cartas; Escrita de si; "Narrativas de vítimas alemãs"; Alemanha pós-Segunda Guerra Mundial; Brasil.

\author{
Méri Frotscher \\ Doutora em História Cultural pela \\ Universidade Federal de Santa Catarina \\ (UFSC), com pós-doutorado pelo Instituto \\ Latino-Americano da Universidade Livre de \\ Berlim. Professora associada da \\ Universidade Estadual do Oeste do Paraná \\ (UNIOESTE). \\ Brasil \\ merikramer@hotmail.com
}

\section{Para citar este artigo: \\ FROTSCHER, Méri. "A miséria me obriga a escrever ao senhor": a escrita de si em cartas de alemães ao prefeito de Blumenau-SC (1946-1948). Revista Tempo e Argumento, Florianópolis, v. 7, n.15, p. 137 - 176. maio/ago. 2015.}

\section{DOI: $10.5965 / 2175180307152015137$}

http://dx.doi.org/10.5965/2175180307152015137

\footnotetext{
${ }^{1}$ Este texto é um dos resultados de projeto de pesquisa financiado pelo CNPq - Conselho Nacional de Desenvolvimento Científico e Tecnológico (Chamada MCTI/CNPq/MEC/CAPES nº 43/2013 e Programa de Bolsa Produtividade). Agradeço ao colega Marcos Nestor Stein e aos dois pareceristas da revista pelas sugestões, visando o aprimoramento da versão final.
} 


\title{
"Need forces me to write to you": the writing of oneself in Germans' letters to the mayor of Blumenau-SC (1946-1948)
}

\begin{abstract}
This article analysis "the writing of oneself" in letters which were sent between 1946 and 1948 from post war Germany to the mayor of Blumenau-SC, Brazil. The requests for gifts and information were accompanied by justifications based on the life conditions and/or the life stories of the senders and the situation of the country. The rhetoric strategies used to interact with the addressee, the image of the city of Blumenau, the mobilization of ethnic national identity and also the tragic narratives of war and postwar time will be analised.
\end{abstract}

Keywords: Letters; Writing of oneself; "Narratives of German victims”; Postwar Germany; Brazil.

Num estado de grande miséria me dirijo ao Senhor em Blumenau/Brasil. $\mathrm{Na}$ Alemanha as fontes de ajuda se esgotaram. Estamos à beira de uma nova catástrofe. A distribuição de mantimentos irá diminuir bastante, novamente, nos próximos meses [...] Como se pode viver com 6.000 gramas de pão, 200 gramas de gordura, 800 gramas de carne e 500 gramas de açúcar por pessoa ao mês? Estamos desesperados. Depois de toda a grande miséria dos últimos anos, agora a grande onda de fome. Na Alemanha ninguém mais pode nos ajudar, por isso eu, minha mulher e meus dois filhos pequenos pedimos ajuda ao Senhor no Brasil. ${ }^{2}$

\footnotetext{
${ }^{2}$ Carta de Rugprecht von B. Freundorf, 26.2.1947. Esta e outras citações de cartas e referências em língua
} 
Com esse preâmbulo, Rugprecht v. B., morador da Baviera, no sudeste da Alemanha - zona de ocupação norte-americana ao término da Segunda Guerra Mundial -, inicia sua carta endereçada, em fevereiro de 1947, a uma autoridade desconhecida no exterior, o prefeito do município de Blumenau, Sul do Brasil, para pedir donativos. Sem alimentos suficientes para sustentar a família, tendo perdido os bens deixados no Leste Europeu, de onde teve que fugir ao final da guerra, a família desse homem de sobrenome nobre lançava mão desse recurso, um apelo escrito em forma de carta, na esperança de obter ajuda de "compatriotas", “os alemães" residentes na brasileira cidade de Blumenau.

A carta de Rugprecht, testemunho daquele tempo de carestia vivido no pósguerra, é uma das missivas endereçadas à prefeitura municipal de Blumenau entre $1946 \mathrm{e}$ 1948, sobre as quais nos debruçaremos neste artigo. O fato de o município ter se originado de um projeto de colonização alemã, isso ainda no século XIX, foi um dos motivos para o envio das cartas, como veremos em detalhes mais adiante. O texto a seguir analisa alguns aspectos dessa prática epistolar específica, a carta-pedido (Bittbrief). São cartas em geral baseadas na "escrita de si", pois os pedidos de donativos ou informações vinham acompanhados de justificativas fundamentadas nas condições de vida circunstanciais e/ou nas histórias de vida dos próprios remetentes.

Essas cartas têm uma especificidade: são cartas-pedido endereçadas a uma autoridade e que estabelecem um primeiro contato e, por isso, dão a conhecer a expectativas dos solicitantes e as diferentes formas pelas quais se autorrepresentam e justificam seus pedidos. Elas nos informam sobre a luta cotidiana pela sobrevivência - daí algumas delas serem identificadas como Notbrief (carta de emergência) -, sobre as consequências da guerra para a vida privada, sobre os destinos trágicos de sobreviventes de bombardeios ou de famílias de alemães evacuados, refugiados ou expulsos de territórios a Leste. Mais do que informar sobre experiências vividas durante e depois da guerra, as cartas permitem apreender os modos pelos quais os escreventes as narram, assim como os ressentimentos em relação à morte de familiares e a perdas materiais e simbólicas. 
Muitas das cartas aqui submetidas à análise impressionam pela dramaticidade das experiências vividas, pelo elemento trágico da narrativa e, claro, pelo principal motivo de sua redação: a carestia de mantimentos. Mesmo assim, contudo, a intensa emotividade, assim como os detalhes do privado nelas presentes, como adverte Teresa Malatian, não devem fazer o historiador prescindir do necessário distanciamento crítico na análise dessas fontes (2011, p. 205). Como também sublinham Maria Helena Bastos, Maria Teresa Cunha e Ana Chrystina Mignot (2002, p. 7), as cartas, "longe de espelharem o que aconteceu de fato", "exigem um esforço interpretativo" que leve em conta as especificidades desse tipo de escrita autobiográfica. As cartas que aqui analisaremos, com essa natureza autobiográfica, são fontes altamente subjetivas. São "escritas de si" nas quais "[...] o indivíduo assume uma posição reflexiva em relação à sua história e ao mundo onde se movimenta." (MALATIAN, 2011, p. 195). ${ }^{3}$

Ao tratarmos de missivas de conteúdo autobiográfico, interessa-nos desenvolver aqui algumas questões, como: -Que experiências, vividas em que momentos, são trazidas à tona pelos remetentes e sobre o que não se escreve? -Que autoimagens são construídas para serem lidas pelo destinatário? -Como a "escrita de si" é conformada pela interlocução com o destinatário e pelas experiências vividas durante e após a guerra, momento no qual os escreventes viviam não somente a carestia, mas também as consequências da guerra e do nazismo?

Para tanto, inicialmente apresento as características do conjunto documental preservado e focalizado neste artigo, as condições de produção e envio das missivas, para depois analisar as formas como os remetentes se dirigem ao destinatário e o imaginário sobre Blumenau e seus habitantes nelas presentes. Em seguida, analiso a própria estruturação das "escritas de si”, a configuração de narrativas trágicas de vida e, para tanto, o jogo entre memória e silenciamento e, ainda, a mobilização da identidade étniconacional na argumentação em prol dos pedidos feitos nas cartas.

\footnotetext{
${ }^{3}$ Sobre a análise de cartas, vide ainda, além dos autores citados, os diversos capítulos sobre escrita epistolar contidos nos livros organizados por Bastos, Cunha, Mignot (2002), Galvão \& Gotlieb (2000) e Gomes (2004). Sobre cartas de migrantes e sua potencialidade para estudos sobre escrita epistolar, cultura escrita e emigração, vide artigo de Blas (2004).
} 


\section{As cartas-pedido: condições de produção e preservação}

O corpus documental analisado neste artigo é constituído por 41 cartas escritas por alemães e recebidas pela administração do município de Blumenau entre 1946 e 1948. São cartas escritas por pessoas que não dispunham mais dos endereços de parentes ou conhecidos que moravam no município e por pessoas que não tinham contato algum. Os ofícios-resposta da prefeitura não fazem parte do conjunto documental preservado

Além dessas cartas, de alguns envelopes e traduções, fazem parte do volume preservado mais cinco cartas, não incorporadas à análise por terem outra tipologia que as cartas aqui em foco ou por extrapolarem o espaço temporal estabelecido para a pesquisa (1946-1948) - período em que a maior parte das cartas foi escrita e que coincidiu com a crise de abastecimento na Alemanha.

As cartas foram localizadas pela autora num acervo em posse de particular em Blumenau, em 2010. ${ }^{4}$ Pouco se sabe sobre as condições e época de arquivamento e de preservação das cartas em foco. Presume-se que as cartas tenham sido reunidas para preservação no início dos anos 1950, pois em folha que antecede as cartas, Christina Deeke Barreto, irmão do prefeito municipal Hercílio Deeke e na época responsável pelo arquivo municipal, anotou o seguinte, à caneta: "Pedidos de informação de estrangeiros dirigidos à Prefeitura, respectivamente Prefeito de Blumenau (em alemão, suponho que não foram respondidas)".

Também não sabemos se as cartas preservadas são apenas uma parte das cartas de mesmo tipo recebidas e, no caso, qual sua proporção em relação ao número total recebido pela prefeitura. Há indicações de que se buscou entregar as cartas recebidas, quando eram mencionados parentes ou conhecidos, quando o paradeiro destes últimos

\footnotetext{
${ }^{4}$ Essas cartas foram reunidas pelo advogado aposentado Niels Deeke num volume encadernado, com capa dura, com o título "Flagelados Alemães - Segunda Grande Guerra", que se encontrava em sua residência, em Blumenau - SC, no momento da pesquisa, em 2010. A localização desse corpus somente foi possível pelo fato de a autora ter conhecimento de que ali se encontravam documentos oriundos de fundos da Prefeitura Municipal de Blumenau. Niels Deeke, hoje falecido, era filho de Hercílio Deeke, prefeito nas gestões de 1951-1956 e 1961-1966, períodos não coincidentes com a maioria das cartas aqui analisadas. Cabe salientar que outras cartas-pedido enviadas da Alemanha pós-guerra a Blumenau não foram encontradas no acervo do Arquivo Histórico Municipal “José Ferreira da Silva”.
} 
considerável número de habitantes, ainda possuía relações sociais de um município provinciano, de modo que não era incomum que funcionários conhecessem o paradeiro de parte das famílias ou pessoas referidas nas cartas. ${ }^{6}$

Das 41 cartas, com exceção de três (escritas em língua inglesa), 38 foram redigidas em língua alemã, o que demonstra, por si só, a representação que os remetentes tinham de Blumenau, como veremos com mais detalhes em item posterior. Aos remetentes parecia, portanto, algo natural escrever em sua própria língua ao destinatário, dirigente de uma cidade conhecida como oriunda de um projeto de imigração e colonização alemã.

Em relação ao período de envio das cartas, 29 das 41 cartas foram escritas na primeira metade de 1947, durante ou logo após o que ficou mais tarde chamado como “inverno da fome”. Quase todas as cartas, com exceção de três, foram escritas antes da efetivação do Plano Marshall, plano norte-americano de reconstrução da economia da Europa Ocidental, anunciado em abril de 1948, e da reforma monetária de junho do mesmo ano.

Em relação aos remetentes, dois terços eram homens, um terço mulheres; praticamente um terço dos signatários menciona terem sido expulsos de áreas no Leste Europeu, então sob a influência da URSS. São cartas escritas por "gente comum", pessoas com diferentes níveis de formação educacional, tanto por pessoas que dispunham do hábito de escrever cartas, de redação bem elaborada e argumentativa, como por pessoas menos afeitas à prática da escrita, de linguagem muito simples. Uma delas foi até mesmo escrita por encomenda, a pedido de uma viúva. Entre os remetentes há pessoas de diversas camadas sociais e profissões, como profissionais liberais, técnicos, trabalhadores, donas de casa, aposentados e agricultores. Não há como proceder a uma classificação precisa das cartas por profissão ou por posição social, uma vez que nem

\footnotetext{
${ }^{5}$ Uma anotação que acompanha um envelope informa que a carta original e a tradução haviam sido entregues à pessoa mencionada pelo remetente.

${ }^{6}$ Em 1949, antes da emancipação de Massaranduba, o município de Blumenau tinha 50.661 habitantes. (BLUMENAU, 1950, p. 247).
} 
todas trazem tais informações. Por conta disso, o estabelecimento de correlações entre as posições sociais dos remetentes e as estratégias retóricas adotadas pode ser feita apenas em relação à parte das cartas.

Das 41 cartas, 24 são manuscritas, 17 datilografadas e em diferentes tipos de papel. Destas últimas, três foram datilografadas em papel timbrado, duas assinadas por comerciantes e uma por remetente cuja profissão não é possível identificar. Todas as cartas seguem um modelo básico, próprio da correspondência, com o texto precedido pela data, local e endereçamento, seguido da despedida e da assinatura, ou seja, seguindo mais ou menos o cerimonial epistolar. Mesmo que as cartas sigam esse esquema, os papéis e envelopes utilizados mostram, em alguns casos, a precariedade material vivida no momento. Um dos remetentes chega a pedir o envio de papel de carta para iniciar correspondência com moradores de Blumenau.

Vale lembrar que esses documentos foram redigidos numa época em que a carta, o cartão-postal e o telegrama eram as únicas formas de correspondência escrita entre as pessoas. Dentre essas formas, a carta representava o melhor recurso para procurar correspondentes que pudessem enviar "pacotes".

Quanto aos pedidos feitos, boa parte das cartas pede mantimentos. Em 20 cartas, de um total de 41, são solicitados alimentos, roupas e calçados. Destas, em 5 são listados alimentos, sempre figurando entre eles o café, produto muito valorizado nas negociações no "mercado negro" que se estabeleceu na Alemanha após a guerra; em 11, são pedidos empregos e informações visando emigração; em 10, endereços de parentes, em geral distantes, ou conhecidos que viviam na cidade; em 4, endereços de habitantes com os quais se pudesse iniciar correspondência; em 2, se pede o encaminhamento de cartas em anexo a famílias da cidade. Muitas vezes, numa mesma carta, era feito mais de um pedido. Os pedidos de comida aparecem em cartas de todas as zonas de ocupação da Alemanha. ${ }^{7}$ O pequeno conjunto documental nos limita as possibilidades de comparação de uma zona em relação a outra, sobre diversos aspectos, entre eles a censura e a autocensura.

\footnotetext{
${ }^{7}$ Entre as cartas encontram-se 18 oriundas da zona de ocupação britânica, 9 da norte-americana, 11 da zona soviética e 3 da zona francesa.
} 
Para entendermos o conteúdo, a forma e a própria existência dessas cartas, apontaremos a seguir alguns elementos acerca das condições de vida na Alemanha logo após a guerra.

\section{A Alemanha pós-guerra: a carestia como estímulo à escrita de cartas-pedido}

Não somente os alemães viviam sérios problemas relacionados à falta de alimentos, vestuário, habitação e fontes de energia após a guerra. Como fazem questão de sublinhar os historiadores Alexander von Plato e Almut Leh, “[...] a guerra e suas consequências foram pelo menos de igual forma incisivas para outros povos, em especial na Europa Oriental, para onde Exército e SS alemãs haviam trazido tantas catástrofes e mortes" (1997, p. 7).

A II Guerra Mundial resultou na morte de 55 milhões de pessoas em todo o mundo. Entre 25 a 30 milhões de civis morreram, 15 milhões somente na Europa. Sofreram com as perdas de vidas, sobretudo, os países do Leste, como URSS e Polônia. Na Alemanha, cerca de 3,64 milhões de civis morreram. Destes, estima-se que foram vítimas de bombardeios de 380.000 a 540.000 pessoas; 2 milhões morreram em razão da fuga e expulsão dos territórios a Leste, que passaram a pertencer à URSS, Polônia, Tchecoslováquia e a outros países que tornaram áreas de influência da URSS. Em 1945, cerca de dois terços dos alemães não estavam em suas casas ou estavam tentando retornar a elas, em razão das evacuações, fugas e expulsões e envio de soldados para prisões de guerra noutros países (VON PLATO, 2000, p. 119-120; VON PLATO \& LEH, 1997, p. 11-14). Ao final da guerra, entre 11 e 18 milhões de alemães fugiram ou foram expulsos diante da chegada das tropas do Exército Vermelho, após os acordos entre URSS e Polônia, ou foram evacuados ou deslocados conforme o Acordo de Potsdam, de agosto de $1945 .{ }^{8}$ O censo de outubro de 1946 indica que, além dos residentes locais e evacuados, quase 10 milhões de expulsos e refugiados alemães oriundos dos territórios do Leste, da

\footnotetext{
${ }^{8}$ Entre outras decisões dessa Conferência, da qual participaram os chefes de Estado dos EUA, URSS e GrãBretanha, ficou estabelecida a entrega do Norte da Prússia Oriental à URSS, a subordinação dos demais territórios ao Leste da linha dos rios Oder e Neisse à administração polonesa e a expulsão das populações alemãs desses territórios e do Leste Europeu de "forma ordenada e humana". (BEDÜRFTIG, 1996, p. 337338).
} 
Esse afluxo populacional num território agora reduzido e as destruições causadas pela guerra agravaram consideravelmente as condições de moradia e de abastecimento de energia e alimentação da população. Sobretudo nas cidades, as condições de vida eram catastróficas, com a destruição ou debilitação da infraestrutura e problemas de abastecimento de alimentos e de energia. Com a derrota da Alemanha, haviam cessado as possibilidades de abastecimento da população com matérias-primas provindas dos territórios antes ocupados pelas tropas alemãs.

Muito embora as autoridades das quatro potências vencedoras, responsáveis pela administração das zonas de ocupação na Alemanha, procurassem garantir uma distribuição controlada de cartões de mantimentos (Lebensmittelkarten), recurso já utilizado durante a guerra, esses eram insuficientes para suprir as necessidades da população (VON PLATO \& LEH, 1997, p. 35). Para piorar a situação, em fins de 1946 e início de 1947, a Alemanha sofreu o "inverno da fome", o inverno mais frio das décadas anteriores. Nesse período, além da insuficiência de fontes energéticas, o sistema de abastecimento da população, já em crise, entrara em colapso.

Foi exatamente nesse momento que um dos remetentes, Rugprecht von B., mencionado na epígrafe deste artigo, se dirigiu ao prefeito de Blumenau para pedir mantimentos. O drama da fome vivido principalmente nas cidades também é descrito por August A., morador da região do Ruhr:

Após a terrível guerra, que abalou todo o mundo, rebentou na Alemanha uma fome que não se deixa descrever por meio de palavras. [...] Nas cidades daqui ocorreram até manifestações por causa da fome. A grande e populosa região industrial às margens do Reno e do Ruhr, onde moro com minha família, é especialmente atingida pela carestia de mantimentos. Falta de tudo [...]. ${ }^{9}$

Como consequência da onda de fome, instaurou-se a prática da busca por alimento no campo e nas florestas. Então surgiram novas fontes de alimentação, novas formas de plantio e, nas cidades, se difundiu a troca de produtos no "mercado negro"

\footnotetext{
${ }^{9}$ Carta de August A. Duisburg, 30.5.1947.
} 
(VON PLATO \& LEH, 1997, p. 36). O principal objetivo de muitos pais e mães era garantir a sobrevivência da família.

Uma das táticas utilizadas pelos alemães também passou a ser a escrita e o envio de cartas a parentes, conhecidos ou mesmo estranhos no exterior para pedir ajuda. A própria profusão dessa prática é reveladora da carência, do estado desesperador de muitas pessoas e de suas expectativas de ajuda nesse momento extraordinário e marcante da história alemã e, também, de suas próprias histórias de vida. Como bem observou a historiadora Ângela de Castro Gomes, guerras e outras circunstâncias excepcionais estimulam a prática da "escrita de si" (2004, p. 18). Como também aponta Verónica Sierra Blas (2004, p. 123), em artigo sobre cartas de emigrantes, as cartas não somente nos falam da experiência de homens e mulheres, mas também são o produto e a consequência direta dela.

O restabelecimento do serviço postal com o exterior possibilitou pedir ajuda, como escreve uma remetente em maio de 1946: "Passou um comunicado pela imprensa alemã, informando que quem tivesse parentes ou amigos no estrangeiro, poderia se comunicar com eles para que mandassem mantimentos". ${ }^{10}$

O envio de cartas foi estimulado pelo recebimento de donativos do exterior, como atesta a carta anteriormente citada, de August A. Ele comenta sobre pacotes recebidos por muitos alemães, antes de pedir que o prefeito e seus concidadãos ajudassem a ele e sua esposa a atenuar-Ihes a "amarga miséria"."11

O envio de CARE-packages às zonas de ocupação norte-americana e inglesa havia sido permitido em junho de 1946 e, para a zona de ocupação francesa, em dezembro do mesmo ano. A Cooperative for American Remittances to Europe, cuja abreviação já é significativa (care = cuidado/preocupação), havia sido criada em 1946 por iniciativa privada nos Estados Unidos com o intuito de minimizar a carestia do pós-guerra na Europa, especialmente na Alemanha, e foi responsável pelo envio de toneladas de donativos (BEDÜRFTIG, 1996, p. 91). Cerca de 9,5 milhões de pacotes, no valor de 362

\footnotetext{
${ }^{10}$ Carta de Elfriede P. Hamburg, 25.5.1946.

${ }^{11}$ Carta de August A. Duisburg, 30.5.1947.
} 
Também outras organizações de ajuda humanitária atuaram no envio de mantimentos à Europa. No Brasil foi criado, em 1946, o "S.O.S. Europa Faminta" - SEF, que atuou entre aquele ano e 1949 com o objetivo de enviar donativos não a toda Europa, mas à Alemanha e à Áustria. Essa organização, segundo Evandro Fernandes, (2005, p. 12) “[...] surgiu a partir da mobilização de elementos representativos inseridos em diversos grupos sociais pertencentes à comunidade étnica alemã no Brasil [...]”, tendo atuado no “[...] contexto urbano e rural das colônias alemãs do sul e sudeste do país". ${ }^{12}$ A atuação da SEF, segundo Fernandes, teria satisfeito os anseios do governo brasileiro, interessado em colaborar com as autoridades norte-americanas no sentido de minimizar o problema do abastecimento da população na Alemanha (p. 46).

No próprio volume de cartas utilizado neste artigo encontra-se uma carta da Liga der Menschlichkeits-Freude [Liga dos Amigos da Humanidade], entidade com sede em Hamburgo, endereçada ao prefeito, rogando "amizade e confiança" e nominando uma série de donativos a serem repassados às vítimas de bombardeios e a refugiados da guerra. Os doadores seriam, segundo o documento, devidamente registrados no "Livro de Ouro dos Amigos da Humanidade". ${ }^{13}$

Um dos signatários das cartas enviadas a Blumenau foi motivado a redigi-la em razão de notícias de recebimento de pacotes oriundos do Brasil: "Enviem a mim, por favor, pacotes com donativos [citados são Liebespackete]. ${ }^{14}$ Eu sei que vocês têm condições, ouvi sobre a beneficência dos teuto-brasileiros e [por isso] me dirijo como peticionário ao Senhor". ${ }^{15}$ Percebe-se aqui, contudo, que o apelo é feito não aos brasileiros em geral, mas aos "teuto-brasileiros".

${ }^{12}$ Cerca de 5.000 cartas de agradecimento fazem parte do acervo Benno Mentz, no Instituto LatinoAmericano de Estudos Avançados da UFRGS, parte delas analisadas por Fernandes (2005, p. 12).

13 Ofício da Liga der Menschlichkeits-Freunde ao Burgomestre da cidade Badenfurt, Santa Catarina, 4.08.1947. Erroneamente o remetente se dirige ao "burgomestre" de um bairro do município de Blumenau, cuja denominação alemã aponta a origem dos imigrantes que ali se estabeleceram.

${ }^{14}$ Em algumas cartas, além de Liebespacket, é utilizada outra expressão em alemão, Liebesgabe, ambas com o prefixo Liebe (amor).

${ }^{15}$ Carta de Albert D. Thaden, 12.2.1947. 
Provavelmente cartas dessa natureza foram enviadas a outras localidades com presença de alemães e descendentes no Brasil e em outros países. Uma carta-padrão escrita à máquina numa via carbonada, por exemplo, na qual se percebe que o destinatário e a data foram inseridos depois, mostra que o mesmo pedido foi feito simultaneamente a diversos destinatários. ${ }^{16}$

Essas cartas eram controladas na Alemanha, antes do envio, pelo serviço de censura das respectivas administrações militares das zonas de ocupação. É o que deixam atestar os adesivos e carimbos apostos em alguns envelopes preservados. ${ }^{17} \mathrm{O}$ conhecimento acerca deste controle provavelmente interferia, mesmo que de maneira implícita, no conteúdo e na forma pela qual as cartas eram escritas.

Quanto ao destinatário das cartas aqui em foco, quase todas se dirigem ao prefeito ou à prefeitura de Blumenau; uma se dirige à "colônia” Blumenau; duas, à polícia local, certamente por se supor que também no Brasil essa instituição fosse responsável pelo registro do endereço dos habitantes; uma se dirige ao (não existente) "Escritório de Informações Pessoais de Blumenau”. De qualquer forma, são cartas endereçadas a uma autoridade desconhecida no exterior, tanto que nenhuma delas se menciona o nome do prefeito em exercício. ${ }^{18}$ As implicações disso para a escrita das cartas serão analisadas a seguir.

\section{A interlocução com o destinatário}

Escrever cartas, como aponta Michel Foucault, significa "[...] mostrar-se, dar-se a ver, fazer aparecer o rosto próprio junto ao outro. E deve-se entender por tal que a carta é simultaneamente um olhar que se volve para o destinatário [...], e uma maneira de o remetente se oferecer ao seu olhar pelo que de si mesmo lhe diz" (FOUCAULT, 1992, p.

\footnotetext{
${ }^{16}$ Carta de Waldemar W. Münster, 23.6.1947.

${ }^{17}$ Teor dos carimbos: "Military censorship - Civil Mails" (zona britânica); “U.S. Civil Censorship” (zona norteamericana). Nos três envelopes oriundos da zona soviética não há carimbos de controle. Da zona francesa não há envelopes no volume de cartas analisado.

18 Entre 1945 e 1948, revezaram-se três políticos no cargo de Prefeito Municipal de Blumenau: Frederico Guilherme Busch Júnior (jan. 1945 a fev. 1946), Germano Beduschi (fev. 1946 a abr. 1947), Bruno Hildebrand (abr. a dez. 1947) e, novamente, Frederico Guilherme Busch Júnior (dez. 1947 a jan. 1951).
} 
150). Esse "face a face", contudo, ainda não se havia concretizado, no caso aqui em análise, pois ainda não se havia estabelecido uma correspondência entre remetente e destinatário. As cartas-pedido foram o primeiro, senão o único, contato estabelecido pelos remetentes com aquele destinatário. Mesmo assim, ele está presente nessa escrita epistolar, pois é pensando nele que os remetentes escrevem.

Nessas cartas, a relação entre remetente e destinatário demonstra também outra especificidade: são missivas, em geral, de pessoas “comuns” para uma autoridade, daí quase todas elas iniciarem com “Excelentíssimo Senhor Prefeito”. Elas revelam traços de uma cultura escrita na qual o endereçamento de uma carta a uma autoridade faz com que ela assuma uma determinada forma, expressa já na saudação, mas também no corpo do texto, no preâmbulo e na despedida. Diferentemente de cartas entre amigos, nas quais há uma relação horizontal e por meio das quais se constitui uma rede de sociabilidades e se expressam afetos e sentimentos, por vezes até íntimos, nas cartas em questão há uma relação verticalizada entre destinatário e remetente. O último deposita no destinatário a esperança de que ele pudesse assisti-lo, muito embora ele fosse autoridade municipal noutro país. O fato de aquela autoridade governar uma cidade com presença de imigrantes e descendentes alemães parece ter influenciado parte dos remetentes a ela recorrerem, como se percebe na carta de Lilli S.: "Ao senhor Prefeito de Blumenau. Uma alemã desconhecida, que se encontra em grande miséria, escreve estas linhas". ${ }^{19}$ Ao se autorrepresentar como "alemã desconhecida", e não meramente como "estrangeira desconhecida", substantivando assim a sua nacionalidade, conscientemente ou não, ela apela para a solidariedade étnica do destinatário. Essa autorrepresentação está conectada com o que ela narra depois, sobretudo as violências e perdas sofridas ao final da guerra no Leste, enquanto alemães.

O apelo à autoridade máxima de um município no exterior faz muitos remetentes, constrangidos, pedirem desculpas já no prólogo, como, por exemplo, Walter P.: “Já de início eu peço desculpas se minha carta lhe causa desconforto e toma o seu tempo. 0 período de miséria atual na Alemanha, pela qual estou, pessoalmente, fortemente

\footnotetext{
${ }^{19}$ Carta de Lilli S., Grünholz, 10. 4.1947.
} 
morreram durante a fuga -, que também é percebida como coletiva, de “[...] todos os alemães que moravam nos territórios [alemães] do Leste [Ostgebiete]”.

Outro exemplo é a carta de Ludwig N., que procura imprimir dignidade àquela escrita indigna (a carta-pedido), já a iniciando com um pedido de desculpas: "O senhor me desculpe, por favor, por me dirigir ao Senhor com um assunto tão extraordinário. Como também será do seu conhecimento, a miséria na Alemanha é muito grande." ${ }^{21} \mathrm{O}$ remetente era funcionário de um banco, uma posição social perceptível por meio da linguagem mais rebuscada. A menção de sua profissão e situação familiar Ihe serve como argumento para fortalecer seu pedido. Ele argumentava que, por ser da classe média, não podia nem comprar produtos no "mercado negro", como os mais abastados faziam, nem receber ajuda de organizações assistenciais, que priorizavam famílias com muitos filhos. Ele menciona a filha de sete anos, segundo ele, carente de suplementos alimentares, para pedir o envio de mantimentos. Também este remetente escolhe e narra fatos em razão de uma situação decorrente das circunstâncias do pós-guerra, situação de carência que ele não quer ser interpretada como uma condição de vida original dele. Por isso, para não comprometer sua dignidade pessoal e posição social, ele faz questão de afirmar sua intenção de pagar pelas despesas do envio do pacote: “Eu declaro expressamente minha disposição em restituir os gastos após a revogação das prescrições cambiais".

Pedir produtos tão básicos à vida a um "ilustre" desconhecido no exterior talvez não fosse tão humilhante e constrangedor do que a um conhecido. Mesmo assim, os remetentes escreviam preâmbulos longos e/ou textos sobre suas vidas para justificar seus pedidos, por meio de narrativas explicativas, devido à preocupação com a forma pela qual o destinatário na cidade iria interpretá-las. Um preâmbulo longo é escrito, por exemplo, por Lilly K., que inicia sua carta trazendo as poucas informações das quais dispunha sobre o destino de um parente distante, um tio-avô, que havia emigrado para

\footnotetext{
${ }^{20}$ Carta de Walter P., Köln, 28.05.1947.

${ }^{21}$ Carta de Ludwig N., München, 15.3.1947.
} 

tão longo tempo. A razão para esta ação é a que segue: As condições de vida são tão péssimas na Alemanha, que eu gostaria de perguntar a essa gente, qual delas poderia e seria bondosa o bastante para me enviar algum alimento". ${ }^{22}$ A remetente havia ouvido notícias sobre o recebimento de donativos vindos do Brasil. A estruturação e a escrita da missiva demonstram um bom grau de instrução e habilidade na redação. Também esta remetente sublinha o intuito de querer pagar pelos mantimentos, assim que a situação econômica e política o permitisse, um meio retórico que visava afastar qualquer possibilidade de ela ser vista como pedinte e, assim, indigna de sua posição social. Exatamente por isso que ela tece, logo em seguida, considerações acerca de sua reputação social e condição econômica: "Tenho o prazer de gozar de elevada reputação e minhas condições financeiras estão em completa ordem. Contudo, eu não consigo vencer a falta de alimentos, vestuário e calçados, pois os mesmos não são obtidos com dinheiro". ${ }^{23}$

Diversas outras estratégias narrativas são utilizadas para estabelecer um contato com o destinatário e tentar mobilizá-lo a ajudar. Em algumas cartas, como na de Hermann H., um pedreiro aposentado de 82 anos, o autor associa elementos de sua autobiografia a Blumenau, onde havia trabalhado 55 anos antes no ramo da construção: “(...) eu ganhava muito bem e agora me arrependo de não ter ficado por lá." Em seguida, Hermann escreve sobre as consequências das guerras mundiais para sua vida em particular: “(...) perdi nas nossas duas guerras tudo o que eu tinha e vivo hoje como refugiado e pedinte". O remetente se autorrepresenta como vítima de duas "expulsões", uma em razão do Tratado de Versalhes, quando a cidade onde morava passou a fazer parte da Polônia, outra em decorrência do avanço das tropas soviéticas, em janeiro de 1945, quando ele,

\footnotetext{
${ }^{22}$ Carta de Lilly K. Essen, 22.3.1947. Tradução para o português de Annemarie Techentin, então funcionária da prefeitura.

${ }^{23}$ Uma anotação feita a posteriori por um funcionário da prefeitura informa que uma cópia da carta foi entregue a familiares, os quais teriam prometido atender ao pedido.
} 
junto com os demais alemães de Breslau, Silésia, foram evacuados às pressas ${ }^{24}$ : "No ano de 1921 a Polônia me expulsou de Graudenz, W/Pr. [Prússia Ocidental] e agora, em 1945, fomos evacuados ou jogados para fora de Breslau. Loja, casa, poupanças, assim como mobília, vestuário, etc., tudo perdido. Nós não temos mais nada". ${ }^{25}$ Esses eventos e a estadia em Blumenau, mencionadas na curta biografia, fundamentam seu pedido de ajuda. Hermann apela para uma suposta solidariedade de ofício, ao solicitar que o prefeito lhe enviasse endereços de donos de empreiteiras locais que pudessem se solidarizar com um “colega de trabalho empobrecido" e lhe mandar um pacote com café e outros alimentos. Este é o único caso de pessoa que já havia morado em Blumenau. As demais cartas preservadas, em geral, até por terem sido endereçadas à Prefeitura, foram escritas ou por pessoas sem relações com moradores da cidade ou por aqueles que tinham parentes muito distantes ou que não tiveram interesse em manter contato. ${ }^{26}$ Alguns casos são exceções, como o de Paul Hippler, que havia perdido o endereço do cunhado: "[...] eu o perdi completamente por causa da fuga, que nos expulsou da pátria”. ${ }^{27}$ Em Blumenau, sobretudo alemães que haviam imigrado no século XX mantinham correspondência com parentes na Alemanha, interrompida por causa da guerra.

Mas no caso dos remetentes que alegavam ter parentes e conhecidos na cidade, há muito tempo não havia mais contato. Michael S., 63 anos, por exemplo, informa alguns elementos de sua tragédia familiar. Seu filho e esposa haviam dele se separado ao emigrarem para o Brasil em 1920, desde quando não teriam tido mais contato. Na carta não é citado o nome da esposa, somente do filho. A informação de que o filho não teria respondido a nenhuma das suas duas cartas, é inclusive, sublinhada. Por meio deste acento ele também justifica o fato de recorrer ao prefeito de Blumenau. De forma bem direta, ele pergunta: "Senhor Prefeito, o senhor conhece o meu filho? Ele ainda vive em

\footnotetext{
${ }^{24}$ A ordem de evacuação foi tomada muito tarde, em janeiro de 1945. Em três semanas, cerca de 700.000 alemães foram evacuados de Breslau, sem meios de transporte suficientes, a baixas temperaturas. Morreram nesta ação em torno de 90.000 pessoas, principalmente crianças e idosos. (ZWANGSUMSIEDLUNG..., 2009, p. 171).

${ }^{25}$ Carta de Hermann H. Leipzig, 3.4.1948.

${ }^{26}$ Somente 15, dos 41 remetentes, afirmam ter parentes no município; destes, 7 parentes de primeiro grau, 8 com grau de parentesco distante.

${ }^{27}$ Carta de Paul H. Bremerhaven-Wulsdorf, 6.8.194[?].
} 

tenha relação com a própria história de separação daquela família e a situação embaraçosa do pedido. Não há indícios na carta sobre a profissão ou posição social do remetente. A interação com o destinatário, estabelecida de forma bem mais direta e menos elaborada, denota menor socialização com a escrita, muito embora a carta tenha todos os elementos comumente utilizados neste tipo de documento. Apesar disso e das poucas palavras, a narrativa logra formar a imagem de um idoso só e desamparado. Outra idosa procurava localizar o filho, pai de cinco filhos, ${ }^{29}$ que havia se instalado em Blumenau e desde 1937 não mandava mais notícias. Esses dois exemplos de pais que procuram filhos são os únicos entre os remetentes, mas são casos de parentes que parecem ter se distanciado propositalmente. ${ }^{30}$

A presença de parentes distantes foi o subterfúgio para o envio de oito cartas. Helmut H., por exemplo, pedia o endereço de uma prima que havia deixado o país nos anos 1920 na grande onda emigratória de alemães rumo ao Brasil. Dela só sabia o nome de solteira e que teria uma fábrica de artigos de couro. ${ }^{31}$ Uma idosa, de 79 anos, por sua vez, pedia, como um de seus últimos desejos, que a prefeitura encaminhasse uma carta anexa aos descendentes de sua tia, com a qual teria mantido contato no passado. ${ }^{32}$

Entre os remetentes há até mesmo aqueles que procuravam contato com conhecidos da família, os quais haviam visto uma única vez. Um professor, por exemplo, usou como recurso para estabelecer algum vínculo com o destinatário, a visita de uma pessoa de Blumenau, quando ainda era adolescente. Muito didática, por sinal, é a forma como esse professor estabelece interlocução com o destinatário: "Eu me dirijo ao Senhor com um pedido de informação. Primeiro devo informar quem eu sou. Sou professor no ginásio em Schwerin [...] Como vim à ideia de Ihe escrever?" Ele explica rapidamente a

\footnotetext{
${ }^{28}$ Carta de Michael S. Wuppertal-Elberfeld, 25.6.1947.

${ }^{29}$ Não fica claro, na carta, se os filhos também moravam em Blumenau.

${ }^{30}$ Carta de Maria B. Warendorf, 24.7.1946.

${ }^{31}$ Carta de Helmut H. Neuenhain (Ober-Taunus), 29.5.1946.

${ }^{32}$ Carta de Maria S. Niederweiler, Kreis Bitburg, 12.4.1948.
} 

mantimentos no país, ele finalmente pede a intercessão da prefeitura para que a família da pessoa mencionada fosse localizada, como pedido de que lhe enviasse um Hilfspacket (Hilfe = ajuda; Packet $=$ pacote $)$, contendo arroz, gordura, sabão, café e tabaco. O quanto o pacote era mais urgente do que o reestabelecimento do contato, evidencia a última frase da carta, na qual ele pede que a carta fosse encaminhada a um "comitê de ajuda", caso não encontrassem a mulher mencionada. ${ }^{33}$

O recurso a conhecidos em Blumenau também é utilizado por Heinz Z., que, de tão confiante na intercessão da prefeitura na localização de uma família, anexa ao seu pedido uma carta manuscrita em grafia caprichada em 3 páginas, diretamente dirigida à ela. A mencionada família havia hospedado seu irmão há muitos anos. Ao apelar àquela "família alemã", o missivista mobilizava uma suposta fraternidade existente entre alemães dos dois lados do Atlântico, tão veiculada pelos nacionalismos alemães. ${ }^{34}$ Desta forma, Heinz englobava moradores da cidade numa espécie de comunidade étnico-nacional, "concebida como um companheirismo profundo e horizontal", mesmo que separados por fronteiras políticas (ANDERSON, 1989, p. 14-16). Mesmo que a mobilização desses elementos fosse apenas $m$ recurso retórico utilizado para sensibilizar o destinatário, a sua subsistência é significativa. Em que pese a derrota do nazismo, esta e outras cartas continuavam a mobilizar uma identidade étnico-nacional.

O discurso de entidades de ajuda humanitária atuantes na Europa também parece ter sido apropriado por alguns dos remetentes, como Albert D., que se dirige ao prefeito e aos “irmãos e irmãs alemães e brasileiros".35

Houve até quem mencionasse ascendentes que haviam emigrado no século XIX, com o objetivo de estabelecer uma ligação com o destinatário. O caso mais extremo é de um agrônomo diplomado, que pedia o paradeiro dos descendentes da viúva de seu

\footnotetext{
${ }^{33}$ Carta de Walter S. Schwerin, 15.5.1947.

${ }^{34}$ Carta de Heinz Z. à família F. Halle/Saale, 23.6.1947.

${ }^{35}$ Carta de Albert D. Rendsburg, 12.2.1947.
} 
Outra tática utilizada era o pedido de viabilização de correspondência postal em língua alemã com moradores da cidade. Talvez esses remetentes não ousassem ser diretos na primeira carta e pretendessem pedir ajuda somente depois de estabelecida correspondência regular com algum morador da cidade. ${ }^{36}$ Chama atenção uma carta de um refugiado, que, na consciência da situação extraordinária em que viviam os alemães, se oferece para responder a perguntas e a relatar sobre o "destino" de seu país a "pessoas alemãs" da cidade: "Me interessa saber como se imagina aí, em geral, a situação na Europa e, em especial na Alemanha. E quais interesses se têm em relação à Alemanha. Em troca, tenho a intenção de responder a desejos e perguntas, e mesmo dar relatos extensos sobre o destino deste país". Nesse aspecto, a carta difere das outras aqui analisadas. O oferecimento de informações, contudo, era condicionado à sua não transformação em "propaganda na imprensa”. O remetente sugeria que a carta fosse encaminhada a uma "sociedade ou clube alemão" da cidade. Não consta da carta a profissão ou ocupação dele no momento. Ele havia sido expulso da Silésia e morava na zona de ocupação soviética da Alemanha. Curiosa também é a saudação ao final da carta: “Receba o senhor e repasse aos alemães daí, especialmente aos oriundos da Silésia, as cordiais saudações de um conterrâneo, expulso dali, aqui nomeado 'Neusiedler', de uma Alemanha moribunda". Com as palavras hier "Neusiedler" genannt [aqui nomeado novo morador], o remetente se utiliza, sarcasticamente, de uma forma eufemística utilizada então na zona soviética para representar os alemães expulsos. Por isso ele utiliza a palavra Neusiedler entre aspas. ${ }^{37}$ Esse termo e também o termo Umsiedler, usados pelas autoridades na zona de ocupação soviética e, depois, na Alemanha Oriental, apagavam os sentidos negativos do termo Vertriebener (expulso), já que as populações alemãs haviam sido expulsas de áreas que ficaram sob a influência da URSS. Além do sarcasmo associado à identificação dada a ele e a outros expulsos, o remetente ainda expressa pessimismo ao

\footnotetext{
${ }^{36}$ As quatro cartas com esse pedido eram oriundas da zona soviética.

${ }^{37}$ Carta de Günter W. Rothenbach/Erzgebirge, 23. 3. 1947.
} 
Talvez a usual troca de mercadorias no "mercado negro" na Alemanha, para quem dispunha de recursos, tenha levado um representante comercial a ter a ideia de pedir que o prefeito intermediasse contato com algum "sério colecionador de selos". Em troca do envio de coleções completas de selos impressos no pós-guerra, ele pedia o envio de café. ${ }^{38}$ Muito embora a carta, de teor breve, tenha sido datilografada em papel timbrado da própria empresa do remetente, o papel era tão antigo que os antigos endereço e nome do banco são riscados e atualizados. A troca de produtos talvez lhe parecesse ser uma forma menos deselegante de pedir mantimentos e, assim, manter sua reputação. E, se observarmos, no geral, a forma como os remetentes se dirigem ao destinatário, uma questão-chave se observa: o desafio parecia ser o de ter que pedir mantimentos a um ilustre estranho, por mais humilhante que aquilo pudesse ser, sem perder a dignidade, daí os recursos narrativos utilizados.

\section{Imaginário e escrita epistolar: o apelo à solidariedade "alemã" no Além-Mar}

As cartas em análise permitem apreender a força desempenhada pelos imaginários sociais na própria produção e envio de cartas. A noção de imaginário é entendida aqui como um "sistema de idéias-imagens que dá significado à realidade, participando, assim, da sua existência" (PESAVENTO, 1995, p. 16). A força do imaginário social na história é apontada também por Bronislaw Baczko (1985, p. 309), que define o imaginário como "[...] uma das forças reguladoras da vida colectiva."

Blumenau não era um nome desconhecido para muitos alemães que haviam tomado conhecimento sobre a emigração e a colonização alemã no Brasil na escola, por meio de publicações ou de conversas. Blumenau foi fundada em 1850 a partir de um projeto particular de colonização, empreendido pelo químico alemão Hermann Bruno Otto Blumenau, com o apoio do Império brasileiro. Com o passar do tempo, o significante “Blumenau" passou a ser relacionado a significados solidificados por uma memória da

\footnotetext{
${ }^{38}$ Carta de Rudolf L. Zwickau, 17.11.1948.
} 
colonização alemã no Além-Mar que representava a localidade como uma das "colônias" alemãs mais importantes. Em relatos de viajantes alemães que estiveram no Brasil até o início da II Guerra Mundial, por exemplo, Blumenau era comumente representada como uma cidade "alemã”, "um pedacinho da Europa” no Brasil (LISBOA, 2011, p. 261). No livro de Karl Grube, de 1916, por exemplo, Blumenau é mencionada poeticamente como "[...] a pérola mais bonita no diadema das localidades alemãs do Brasil” (p. 93). As características “alemãs' ou “teuto-brasileiras” de Blumenau ou do Vale do Itajaí eram também comumente veiculadas em livros sobre imigração e colonização publicados na Alemanha, como no Hugo Grothe, de 1936, no qual a paisagem de Blumenau o motiva a representá-la como "Turíngia brasileira” (p.183).

Por conta dessa dimensão simbólica, associada à localidade, uma das cartas foi endereçada "Ao Prefeito da cidade de Blumenau, América do Sul - colônia alemã". ${ }^{39} \mathrm{~A}$ menção à palavra "colônia” aparece também no envelope de outra carta, endereçada à “Administração da cidade - colônia Blumenau”. ${ }^{40}$ Aqui a signatária representa Blumenau como cidade e também colônia, muito embora essa última denominação não fosse oficialmente usada desde fins do século XIX, quando a colônia Blumenau se emancipou e se instalou o município.

Para outra remetente, uma idosa de baixo nível de escolaridade, perceptível pela grande dificuldade de redação, problemas ortográfico-gramaticais e mesmo de grafia, as informações de que dispunha sobre Blumenau eram tão vagas, que imaginava estar a localidade situada nos Estados Unidos da América. Surpreendentemente isso não impediu que a carta chegasse ao seu destino. ${ }^{41}$ Outro remetente, um agricultor expulso da Pomerânia, de linguagem também muito simples e direta, curiosamente pedia que o prefeito descobrisse o paradeiro de seus tios que haviam se dirigido a Minnesota, EUA: “Eu também tenho parentes aí em Minnesota." O objetivo principal do remetente era pedir informações sobre a possibilidade de se instalar em Blumenau como agricultor. A partícula "aí" aproxima duas localidades muito distantes. Muito embora as palavras Amerika e Amerikaner fossem usadas na Alemanha como sinônimo para "América do

\footnotetext{
${ }^{39}$ Carta de Helga P. Essen, 25.4.194[?].

${ }^{40}$ Carta de Willy W. Annaberg/Erzgebirge, 12.6.1947.

${ }^{41}$ Carta de Cecilie D. Köln/Flittard, 20.7.1947.
} 

importasse fosse uma ex-colônia alemã no Sul do Brasil ou uma localidade com presença alemã no interior dos EUA. ${ }^{42}$

A associação com os EUA não é nada estranha, se considerarmos que $90 \%$ dos emigrantes alemães havia se dirigido para aquele país ao longo do século XIX e início do XX. Por conta dessa experiência histórico-cultural, segundo Carsten Würmann (2008, p. 282), emergiu a figura do “Onkel aus Amerika” (tio da América) na cultura alemã, uma expressão idiomática associada à imagem do emigrante bem-sucedido e que, com o passar do tempo, passou a ser utilizada não somente em relação aos que emigraram para os EUA, mas também para outros países do Além-Mar. A figura do "tio rico da América" ressurge depois da II Guerra Mundial como representação positiva em função da ajuda norte-americana aos alemães, com care packages e dinheiro, e também de sua política na zona de ocupação norte-americana da Alemanha, onde "[...] começaram a desempenhar o papel daquilo que facilmente poderia ser comparado à imagem do tio como benfeitor" (2008, p. 288). Segundo o historiador Hermann Glaser, os próprios care packages, por conta do farto e desejado conteúdo - mantimentos, vestuário, medicamentos - e até mesmo da aparência impressionante do embrulho, contribuíram para espalhar o mito do “belo novo mundo" (1997, p. 36).

A falta de amigos ou conhecidos na "América" - como alguns se referiam aos EUA - e a permanência de um imaginário sobre a presença alemã no Brasil, fez Elsbeth, uma das remetentes, assim iniciar sua carta, redigida em inglês: "Senhor! Muitos alemães têm parentes na América, para quem podem escrever uma carta para pedir ajuda. Meu marido, minha filha de 19 anos, meu filho de 17 e eu, contudo, não temos nenhum". O destinatário em Blumenau parecia ser um substitutivo àquele "tio da América" tão almejado. Na compreensão de Elsbeth, cuja família havia sido expulsa da Prússia Oriental, a carência de alimentos e vestuário poderia ser minimizada pela solidariedade de uma

\footnotetext{
${ }^{42}$ Carta de Ernst B. Altkehdingen/Bezirk Hamburg, 15.3. 1947.
} 
“família alemã" de Blumenau, como ela se refere no post scriptum, este redigido em língua alemã, talvez não por acaso:

Ao olhar o mapa da América num atlas emprestado, meu olhar recaiu sobre o nome alemão "Blumenau". Isso me motivou a me dirigir ao Senhor, com meu pedido, na esperança de que talvez pudesse vir ajuda dali. [...] talvez se encontre de longe uma família alemã, a qual queira nos ajudar a sair desta situação nessa época difícil. ${ }^{43}$

Em mapas do Brasil ou até mesmo da América Latina inseridos em alguns atlas alemães podemos perceber o destaque dado a Blumenau. Em atlas escolar publicado durante o regime nazista, por exemplo, entre as quatro localidades do estado de Santa Catarina nominadas, Blumenau é indicada com letras maiores que as demais, inclusive a capital do estado (DIERCKE, [ s.d.], p. 70-71).

Àquele apelo a uma "família alemã" subjaz a compreensão, existente já no final do século XIX, de que também alemães e descendentes fora das fronteiras políticas do Império Alemão eram ligados biológica e culturalmente aos "Reichsdeutsche" (cidadãos alemães) do país. ${ }^{44}$ Talvez por isso que o apelo de Elsbeth tenha sido escrito em alemão e não em inglês, como o corpo da carta. A ela, mas principalmente a outros remetentes que escrevem a carta inteira em alemão, a opção de recorrer a alemães e descendentes fora da Alemanha, então ocupada pelas forças militares de países que haviam sido inimigos durante a guerra, repousava em autopercepções e identificações étnico-nacionais preexistentes.

Apesar da derrota alemã e do fim da Alemanha de Hitler, perdurava na Alemanha uma autopercepção dos alemães como uma Volksgemeinschaft (comunidade racial e nacional alemã), existente já antes do regime nazista, mas levada às últimas consequências durante esse governo. Como bem observou o historiador Malte Thiessen, depois da guerra não houve o desaparecimento total daquela autopercepção, mas se tratava então de uma "Volksgemeinschaft sem Führer". Segundo ele, embora a guerra tivesse causado profundas fissuras entre os alemães, a derrota tornou-se um ponto de

\footnotetext{
${ }^{43}$ Carta de Elsbeth T. Wittingen, 14.06.1947.

${ }^{44}$ MORAES (2002, p. 33). Como o autor observa, o conceito "Auslandsdeutsche" ("alemães no exterior") foi tomando cada vez mais peso, até ser institucionalizado e os "alemães no exterior" serem alvo de uma política de germanidade durante a República de Weimar. Sobre essa política, vide Rinke (1996).
} 
referência em comum na configuração de uma Opfergemeinschaft (comunidade de vítimas). Esse termo era a “[...] expressão de uma experiência coletiva e, simultaneamente, área de projeção para a maior parte dos alemães que encontravam, nessa auto-percepção, respostas oportunas a perguntas do momento" (THIEßEN, 2009, p. 169-170).

O apelo à solidariedade étnica é perceptível também noutras cartas, como na citada na epígrafe deste artigo. O autor, Rugprecht von B., na sequência ao trecho citado, fazia um apelo especial à "caridade" e à "misericórdia cristãs", sobretudo dos "nossos compatriotas, os alemães", moradores de Blumenau. Segundo ele, aqueles só saberiam da carestia vivida na Alemanha por meio dos jornais, pois não a teriam "vivido na própria carne”. Apesar dessa diferença, o remetente os vê como “compatriotas" e apela para sua solidariedade. ${ }^{45}$

Também na despedida da carta de uma senhora de 56 anos, ela apela para a fraternidade dos "meus irmãos e irmãs alemães". Já no início da carta a signatária se referia a Blumenau como "colônia alemã": "Eu gostaria tanto de me mudar para uma colônia alemã e ali me estabelecer como professora de piano. O senhor não teria emprego para mim em sua bela Blumenau, sobre a qual eu tanto li e ouvi falar?" ${ }^{46}$ As informações que a remetente tinha da cidade eram tão escassas, contudo, que ela faz diversas perguntas sobre a cidade na mesma carta.

A imagem de Blumenau como "colônia alemã" levou outros remetentes, entre eles refugiados e expulsos, a considerarem a possibilidade de ali se estabelecerem como "colonos", assim que fosse novamente permitida a emigração. ${ }^{47}$

Também o imaginário que associava o Brasil à fartura de alimentos, em especial o café, tão valorizado na Europa, motivou a redação de diversos pedidos. Um deles foi assim expresso por um remetente: “Aqui, nós todos sentimos falta do café em grão ${ }^{48}$ de

\footnotetext{
${ }^{45}$ Carta de Rugprecht von B. Freundorf, 26.2.1947.

${ }^{46}$ Carta de Gertrud H. Jüterbog, 24.5.1947.

47 As limitações à saída da Alemanha ocidental foram revogadas pelas autoridades de ocupação inglesas e norte-americanas somente em julho de 1949. Sobre a emigração da Alemanha ocidental entre 1945 e 1961, vide Steinert (1995, p. 40 e seguintes).

${ }^{48} \mathrm{O}$ autor se refere a "Bohnenkaffee" (café em grãos). Naquele período, as dificuldades de obtê-lo faziam
} 
vocês, que aí é queimado ou jogado no mar. [...] Se eu recebê-lo, irei trocar uma parte por trigo". ${ }^{49}$ A destruição de grandes quantidades de café, por ocasião da crise de 1929, havia ficado na memória coletiva de muitos brasileiros e também daquele remetente. ${ }^{50}$ Hermann havia trabalhado como pedreiro 55 anos antes em Blumenau, e com nostalgia relembrava dessa estadia, quando teria ganho muito dinheiro: “[...] me arrependo, agora, de não ter ficado por aí". Essa confissão em tom nostálgico, afirmada em comparação à situação vivida então na Alemanha, valoriza a cidade governada pelo destinatário, como forma de sensibilizá-lo. Na despedida, como em outras partes da carta, escreve de forma patética: "Eu gostaria de hoje rever Blumenau, como Blumenau [repetição no original] deve ser uma bela comunidade". ${ }^{51}$

Apesar de que nem todas as cartas apelassem para a solidariedade étnica, o mero fato de terem sido escritas em alemão e enviadas à prefeitura de Blumenau demonstra a força das representações e do imaginário na história ou, no caso aqui em particular, na prática da escrita de cartas.

\section{"Escrita de si" e narrativas trágicas da guerra e do pós-guerra}

$\mathrm{Na}$ análise aqui empreendida, cabe-nos considerar "[...] os suportes materiais da escrita de si, a partir do próprio texto" (GOMES, 2004, p. 17). Nesse aspecto, observamos que a descrição das precárias condições de vida na Alemanha ou até mesmo breves histórias da vida dos remetentes estruturam as narrativas das cartas-pedido, devido à interação que se quer estabelecer com o destinatário. Sobre a "escrita de si" presente em cartas, assim formula Antônio Castillo Gomez: “[...] a materialização escrita da experiência pessoal é inseparável do pacto estabelecido com o leitor real, normalmente o destinatário" (2002, p. 23).

com que fosse consumido "café" feito de outras matérias-primas.

${ }^{49}$ Carta de Hermann H, Leipzig, 3.4.1948.

${ }^{50}$ A destruição de grandes quantidades de café, em 1929, é rememorada até mesmo numa música, de 1932, cantada pelo socialista Ernst Busch, intitulada "Ballade von den Säckeschmeissern" (Balada dos destruidores de sacos de café)". Música de Hans Eissler, texto de autoria de Julian Arendt e Ernst Busch. In: ERNST BUSCH. Lieder der Arbeiterklasse \& Lieder aus dem spanischen Bürgerkrieg. Dortmund: Verlag 'pläne` GmbH. 1 CD. Faixa 10.

${ }^{51}$ Carta de Hermann H., Leipzig, 3.4.1948. 
Considerando ser o destinatário uma autoridade da qual se esperava auxílio, mas que também poderia tomar como indigna a imagem do demandante, a carta tinha que lidar com o desafio de pedir ajuda e, ao mesmo tempo, imprimir um caráter digno àquele gesto indigno, daí os diversos recursos narrativos utilizados, como as desculpas. Os remetentes tinham que descrever a situação-limite vivida naquelas circunstâncias, como argumento para o pedido emergencial, mas de forma a não comprometer sua dignidade pessoal. Nesse aspecto, essas cartas permitem pensar o indivíduo não como algo pronto, mas “como o personagem de si mesmo", como aponta Ângela de Castro Gomes (2004, p. 17).

Nessas cartas-pedido, a "escrita de si” cumpre um papel fundamental, pois ela é “[...] marcada pela busca de um 'efeito de verdade' [...] que se exprime pela primeira pessoa do singular e que traduz a intenção de revelar dimensões 'íntimas e profundas' do indivíduo que assume sua autoria" (GOMES, 2004, p. 14-15). Não é a descrição da conjuntura vivida pela população alemã, mas a narração da situação vivida no presente pelos próprios remetentes, ou seja, a "sinceridade do indivíduo" que busca esse "efeito de verdade", pois é exatamente na subjetividade que se assenta a autoridade, a legitimidade como "prova" de toda escrita de si (GOMES, 2004, p. 15).

Essas considerações são perceptíveis, por exemplo, na carta de Cecilie, uma senhora de 66 anos, que, apesar de doente e da dificuldade de redação - a carta possui erros ortográficos, de formulação e até mesmo de grafia - redigiu a próprio punho uma “carta de emergência” (Notbrief), com os seguintes dados autobiográficos:

Sofro do coração, fraqueza dos nervos, veias das pernas doentes. Em 1943 tudo perdido pelas bombas. Roupa, vestuário, tudo queimado. Toda a família não possui mais nada. Casas, todas queimadas. Sem teto há anos. Pequena pensão. Muito caro tudo, não posso viver da pensão. Muito fraca para trabalhar. Admissão há 8 dias no asilo. Peço desculpas, senhor prefeito, essa carta para o senhor..$^{52}$

Ao discorrer sobre a prática da escrita autobiográfica, Philippe Artières (1998, p. 11) assim se refere ao trabalho da narrativa: “[...] não só escolhemos alguns acontecimentos, como os ordenamos numa narrativa; a escolha e a classificação dos acontecimentos

\footnotetext{
${ }^{52}$ Carta de Cecilie D. Köln/Flittard, 20.7.1947.
} 
determinam o sentido que desejamos dar às nossas vidas". Se atentarmos para a narrativa do trecho acima citado, percebe-se que ela apresenta um "eu” frágil e carente. Diversos adjetivos - “doentes”, “perdido”, “queimado”, “pequena”, “fraca” - e advérbios - "sem”, “nada”, “toda”, “tudo" - ajudam a compor uma autoimagem de mulher carente de ajuda. Nessa narrativa sobressai a perda dos bens em razão do bombardeio, a saúde debilitada e a carência material. Sua condição de idosa desamparada é reforçada ao final da carta, após a saudação final, onde acrescenta a informação: "viúva desde 1941". Cecilie pedia que a carta fosse repassada a uma "mulher caridosa", apelando assim para uma suposta caridade feminina e não, como outros remetentes, à solidariedade étnica.

O baixo grau de instrução e de socialização com a escrita, perceptível na carta acima citada, faz com que a linguagem empregada se pareça com a de um telegrama. Essa linguagem e o perfil da remetente diferem dos de outros remetentes, mas ele é um exemplo, entre muitos outros, de como a "escrita de si" - seja para se referir ao presente ou ao passado recente - fundamentava a produção e envio das cartas-pedido.

Os remetentes discorrem sobre suas vidas naquela conjuntura, detendo-se na descrição da carestia. O passado rememorado, quando mencionado, se refere quase que apenas às perdas e aos prejuízos ocasionados pela guerra. Sobretudo as cartas de expulsos são marcadas pela tragicidade.

As narrativas mais dramáticas, entre as cartas analisadas, são as dos evacuados, refugiados ou expulsos, que haviam perdido não só suas casas, tal como as vítimas dos bombardeios, mas também a pátria, como sempre acentuam, e, assim, a esperança de poderem voltar a suas cidades natais, por agora fazerem parte dos territórios da Polônia, URSS, Tchecoslováquia ou outros países. ${ }^{53}$ Dependendo da posição social e grau de instrução, essas narrativas marcadas pela tragicidade são mais ou menos elaboradas.

\footnotetext{
${ }^{53}$ A representação de um "Leste alemão perdido" tornou-se muito presente na esfera pública da Alemanha Ocidental depois da guerra. Essa ideia já está presente nas cartas aqui analisadas, muito embora ainda não esteja carregada pelo tom nostálgico de momentos posteriores. Sobre a "cultura da pátria" perdida desenvolvida entre os expulsos do Leste, Centro e Sudeste europeus na Alemanha, vide, entre outros, Hahn \& Hahn (2005); Kossert (2009); sobre a "pátria da memória”, vide Demshuk (2012).
} 
A anteriormente mencionada Lilli S., que se apresenta como "alemã desconhecida", por exemplo, demonstra outra linguagem que a de outros expulsos de origem camponesa. Ela era esposa de ex-administrador de grandes propriedades agrícolas na Silésia, parceladas pelos russos após a expulsão dos alemães. Em sua carta, ela escreve em nome do casal. Ela escreve detalhes dramáticos da expulsão, já nas primeiras linhas, compondo uma sequência de cenas muito vívidas:

Meu marido e eu fomos expulsos da província pátria, Silésia, e todos fomos saqueados pelos russos e pelos poloneses, de forma que não possuímos mais nada. Eu tenho 42 anos e meu marido é mais velho. $\mathrm{Na}$ meia noite do dia 8 de março de 1945, o comandante local russo de Künzendorf, distrito Glogau, Silésia, me tirou da cama e quis me prender e sequestrar. Meu marido partiu em minha defesa e se colocou entre nós, depois do que o comandante local the desferiu um golpe na parte superior do crânio que, devido à força, o fez desmaiar e sangrar muito. Nesse tumulto, eu escapei [...] Desde o ocorrido, meu marido está doente. No momento estamos alojados, de modo muito primitivo, na província de Schleswig Holstein. ${ }^{54}$

Diferentemente de Hermann, anteriormente mencionado, que havia deixado a Silésia semanas antes, junto com a massa de evacuados, Lilli e seu marido haviam lá permanecido. Lilli perguntava na carta se havia a possibilidade de se instalarem em Blumenau, como seu tio paterno, já falecido, o fizera tempos antes, ou se conhecidos da família poderiam enviar mantimentos.

Sobre a estruturação da narrativa, o trecho citado acima, mais o parágrafo seguinte, no qual a remetente aborda as difíceis condições de vida, a falta de perspectivas de trabalho para o marido e expressa medo em relação ao futuro dos refugiados alemães, perfazem dois terços da carta. O foco da narrativa é, portanto, a expulsão e suas consequências, compondo, assim, uma das mais contundentes "narrativas de vítimas alemãs" presentes nas cartas. ${ }^{55}$ Esse tipo de narrativa, aqui circunscrito aos limites de uma carta, parece ser possível apenas por se imaginar que o destinatário, por ser

\footnotetext{
${ }^{54}$ Carta de Lilli S. Grünholz, 10.4.1947.

55 Aleida Assmann utiliza o termo "narrativa de vítima alemã" em capítulo em que analisa a profusão, na listeratura e na mídia alemãs, de narrativas sobre os bombardeios a cidades alemãs e a expulsão de alemães do Leste, principalmente a partir de 1995. (2007, p. 183-204).
} 
O leitor já percebe a posição social desfrutada pelo casal na Silésia no trecho em que ela narra o confronto direto entre seu marido e o comandante russo. A estratégia retórica dessa remetente, portanto, era a de expor a trágica história daquele casal, mais especificamente do marido, cujo prestígio e dignidade haviam sido também perdidos pela guerra, por meio da qual ele havia sido rebaixado à situação de refugiado de guerra.

Nem todas as cartas narram a fuga ou a expulsão com ressentimento. O tipo de narrativa escolhido por Otto Mehnert, por exemplo, é mais explicativo, diante da complexidade de sua estória:

\section{Excelentíssimo Senhor Prefeito!}

Já na escola aprendemos sobre a bela colônia alemã Blumenau e, também depois, muito ouvimos falar sobre ela. Como atualmente somos pessoas demais na Alemanha, nos dirigimos ao Senhor, Excelentíssimo Senhor Prefeito de Blumenau, para vos perguntar se não haveria também para nós um lugarzinho em sua colônia. Eu sou agricultor, no momento com 36 anos, minha mulher é professora. Nós somos alemães, mas nascemos e crescemos na Letônia. Até 01.09.1939 éramos cidadãos letos e vivíamos na Letônia. Em novembro de 1939 fomos deslocados para a Alemanha, em dezembro nos tornamos "Reichsdeutsche" [cidadãos alemães] e fomos estabelecidos em Warthegau. De lá fugimos para cá em janeiro de 1945 e desde então não temos nem casa, nem um emprego razoável. Nós lhe pedimos nos escrever se podemos [ir] para sua colônia e como podemos nos preparar para isso. Nos escreva também, por favor, dizendo se há um consulado brasileiro na Alemanha e onde ele se localiza. ${ }^{56}$

Querer se instalar em Blumenau como agricultor provavelmente tinha a ver não somente sobre o que Otto havia ouvido sobre a imigração alemã no Brasil, mas também com sua própria participação na "colonização" ou "germanização", como havia se referido o governo nazista, da Polônia ocupada em 1939. O fato de eles terem sido deslocados da Letônia para a Alemanha antes disso, ação que ficou à época conhecida por meio do slogan nacional-socialista "heim ins Reich", é narrado sem este tom. ${ }^{57} \mathrm{O}$

\footnotetext{
${ }^{56}$ Carta de Otto M. Holstein, 16.3.1947.

57 O deslocamento dessas pessoas ocorreu por conta da assinatura do Pacto Ribbentrop-Molotov, que dividiu o centro da Europa entre Alemanha e URSS em agosto de 1939, pouco antes da invasão da
} 
termo "Reichsdeutsche", usado para se referir aos cidadãos alemães, é cuidadosamente usado entre aspas. Um total de 867.000 alemães e descendentes de diferentes áreas da Europa, entre eles 69.000 da Letônia, foram estabelecidos na Polônia ocupada entre 1939 e 1944 (ZWANGSUMSIEDLUNG..., 2009, p. 163). Eles sofreram deslocamentos forçados por duas vezes entre 1939 e 1945. Em seguida à sucessão de deslocamentos narrados, Otto menciona sua intenção de emigrar para o Brasil, desta vez voluntariamente, mobilizando, para tanto, o que sabia sobre aquela "bela colônia alemã".

Em cartas de remetentes oriundos das províncias da Silésia, Pomerânia e Prússia Oriental, parte do antigo território alemão até 1945, é corrente a menção à perda da “pátria” em razão da evacuação, fuga e expulsão. São exatamente essas histórias de vida que trazem os elementos potencialmente mais comovedores na argumentação em prol da solidariedade. Eles, contudo, não foram reconhecidos pelos poloneses e russos como expulsos, por entenderem que eles haviam sido deslocados de volta para a sua pátria e não terem sido expulsos para outra (VON PLATO \& LEH, p. 18). Daí serem usados outros termos para caracterizá-los na zona soviética de ocupação da Alemanha.

Não era assim, contudo, que viam os remetentes. A constatação de perdas irreparáveis assume um tom trágico na carta de um refugiado de nome Walther P., também pedreiro, que havia perdido não somente o lar, mas também os pais durante a fuga:

Meus pais e eu, com minha família, morávamos também em Schilvebein/Pomerânia, até sermos expulsos pelos poloneses após a guerra, ficando sem dinheiro e sem pertences, como todos os alemães que moravam nos territórios alemães do Leste. Os meus pais, ambos, morreram durante a fuga. Com isso, perdemos o endereço dos nossos parentes que vivem na América. Só sei que eles vivem na sua cidade. Eu fui recebido aqui na Alemanha Ocidental, comarca de Colônia, na condição de refugiado. Somente quem viu, com seus próprios olhos, a miséria dos refugiados, na atual Alemanha, pode ter uma ideia do que isso significa. Na nossa pátria a Leste tivemos que abandonar praticamente tudo o que nós adquirimos ao longo de anos de muito trabalho e economia. Já fazem mais de dois anos que vivemos sem vestuário e calçados adequados, sem móveis e sem utensílios domésticos. Mas o mais terrível é a falta de comida. ${ }^{58}$

Polônia.

${ }^{58}$ Carta de Walter P. Köln, 28.05.1947. 
Em razão do desfecho da guerra, haviam se somado, à população já existente na Alemanha, cerca 9,5 milhões de pessoas evacuadas, refugiadas e expulsas das áreas que ficaram sob a influência da URSS. Essas pessoas moravam espremidas em campos de refugiados ou em cômodos disponibilizados em residências de famílias que tiveram que alojá-los (BENZ, 1995, p. 87). Ali tiveram que procurar se adaptar e lutar pela sobrevivência nos novos locais, onde, muitas vezes, conviveram com a indiferença ou até mesmo a culpabilização por parte dos estabelecidos. Para os refugiados e expulsos que, até 1945, haviam se dedicado à agricultura, era difícil se adaptar noutro contexto, sobretudo o urbano, sem propriedade e sem outra formação profissional, como expressam alguns dos remetentes. O problema do desemprego era mais crônico entre os refugiados e expulsos, que, em 1946, perfaziam 34,3\% do número total de desempregados. Também eles constituíam significativa parcela dos que recebiam ajuda social (VON PLATO \& LEH, 1997, p. 41-42).

Os ressentimentos associados à condição de refugiado são expressos por Albert D., oriundo da Prússia Oriental, que escreve sua carta durante o duro inverno de 1946/47:

Eu sou refugiado e fui expulso de minha pátria Angerburg e perdi tudo, casa, pertences e as terras, assim como a existência. O polonês roubou e tomou posse de tudo. São condições tristes, sob as quais eu e minha família somos obrigados a viver. Nesse rigoroso inverno precisamos dormir, esfomeados e com frio, em trapos rasgados num espaço frio, somos os mais pobres entre os pobres, sem pátria, sem esperança na melhoria da situação e sem esperança de um retorno à pátria querida, isso é muito amargo, meus senhores. Seria desesperador, se não tivéssemos a confiança em Deus [...] Eu asseguro que não possuo nem salário, nem bens, e que tenho de custear a sobrevivência de minha família com os parcos recursos da assistência social. Sem trabalho, sem ganho, me tornei um enfraquecido recebedor de esmolas. ${ }^{59}$

O tom da carta de Albert é marcado pelo ressentimento, pela narrativa trágica e pela expressão da falta de expectativas. O ressentimento é expresso por um viés étniconacional, perceptível pela própria singularização do substantivo “polonês”. Esse outro singularizado aparece como responsável pelo sofrimento e por todas as perdas havidas ao final da guerra. Na carta, diversos são os prejuízos arrolados, desde a perda da casa,

\footnotetext{
${ }^{59}$ Carta de Alberto D. Thaden, 12.2.1947.
} 
dos pertences, da terra, "da existência”, em razão de Albert não poder mais trabalhar como agricultor, até a perda da pátria e da própria esperança em voltar a vê-la. Se a “[...] versão imaginária da falta, no ressentimento, é interpretada como prejuízo [...]”, como explica a psicanalista Maria Rita Kehl (2004, p. 11), o responsável por esse prejuízo nessa e outras cartas é atribuído aos poloneses e russos, inimigos durante a guerra e assim também vistos depois.

Significativo é o fato de a representação dos russos e dos poloneses, como aqueles que expulsaram e usurparam os bens e a "pátria alemã" no Leste, aparecer somente nas cartas escritas nas zonas que não estavam sob a administração soviética. Esse fato pode estar relacionado à autocensura dos seus moradores, diante da censura promovida pelas autoridades soviéticas, que silenciavam sobre as ações violentas contra as populações alemãs no Leste ao final da guerra e dos destinos trágicos de muitos refugiados e expulsos, durante e logo após a chegada das tropas soviéticas.

Além de russos e poloneses, também os franceses são alvo de crítica, mesmo que indireta, numa carta curiosamente enviada da zona de ocupação francesa. Uma senhora veicula a seus parentes, numa carta em anexo à encaminhada ao prefeito, a imagem positiva dos norte-americanos, em detrimento dos franceses:

$\mathrm{Na}$ esperança de que viessem tempos melhores para nós, todos nos alegramos muito quando os americanos chegaram. Mas eles não ficaram aqui por muito tempo. Então fomos entregues aos franceses. Por alguns anos não pudemos mais comprar roupas. Até acontece de vermos pessoas caminharem pelas ruas sem sapatos e sem meias. Nós nos encontramos numa situação emergencial. ${ }^{60}$

Muito embora os norte-americanos sejam vistos pela população alemã, após a guerra, como o “inimigo amigável” (GLASER, 1997, p. 35), antigos medos, ressentimentos e preconceitos em relação a outros povos, como se pode depreender da carta acima e de outras, subsistiram.

\section{Esquecimento e silenciamento nas "escritas de si"}

\footnotetext{
${ }^{60}$ Carta de Maria S. Niederweiler/Kreis Bitburg, 12.4.1948.
} 
Todos os remetentes, com exceção de um, se autorrepresentam nas cartas como vítimas da guerra e da carestia vivida desde então. Não há o reconhecimento de outras vítimas, a não ser o povo alemão. Na narrativa delas, o tempo mais focalizado é o presente, pois, para a maioria dos remetentes, tratava-se de garantir a sobrevivência hodierna. Quando se referem ao passado, são rememorados eventos de um passado mais recente, a partir da metade da guerra, quando a população civil começara a sofrer os bombardeios e a carência de mantimentos. Interessante é observar que nenhum dos 27 remetentes masculinos escreve ter participado da guerra como soldado. Quanto ao futuro, nas cartas ele é apreendido como um tempo incerto, envolto em pessimismo ou deixado nas mãos de Deus.

A única carta na qual o sofrimento e a carestia causados pela guerra são estendidos a toda a humanidade e na qual se escreve sobre "culpa" e necessidade de reparação, relacionadas ao "povo alemão", é uma endereçada diretamente a uma família residente em Blumenau, anexa a uma carta ao prefeito, anteriormente mencionada. A família hospedara, há muitos anos, o irmão do remetente, então marinheiro. Pelos dados apresentados, muito provável tratar-se da visita da tripulação do cruzador Karlsruhe, recebida de forma solene em 1934. Talvez justamente pelo fato de escrever diretamente a uma "família alemã"- assim Heinz se refere -, muito embora ele não a conhecesse, que ele tenha refletido mais sobre o passado e compartilhado o seguinte:

Essa guerra terrível trouxe muito sofrimento e miséria amarga para a humanidade. Especialmente nós, alemães, lançamos uma bela culpa sobre nós e precisamos agora recuperar a confiança dos outros povos da Europa e de todo o restante do mundo através de forma pacífica e reparar todas as atrocidades cometidas. Mas ainda demorará muito tempo até que o povo alemão obtenha novamente reputação no mundo e seja admitido na grande comunidade dos povos. Somente então teremos uma vida melhor. No momento, todos nós sofremos uma pesada crise alimentar e sobrevivemos numa época difícil na luta pelo pão de cada dia. Disso sofrem principalmente as crianças inocentes. Eu também sou casado e tenho uma pequena menina de três anos. Obviamente eu também cuido, até onde minhas forças me permitirem, de minha mãe, que, como viúva, também vive sozinha e sem recursos. ${ }^{61}$

\footnotetext{
${ }^{61}$ Carta de Heinz Z. Halle/Saale, 23.6.1947.
} 
$\mathrm{Na}$ carta, cujo objetivo é pedir um "pequeno pacote", a reparação das “atrocidades cometidas" e a recuperação da "confiança dos outros povos" são vistas como tarefas de longo prazo. Também para o remetente, a luta pela saúde da família é a urgência do momento. Em que pese a declaração de uma "culpa alemã", permanece a ideia da necessidade da solidariedade entre os alemães, até mesmo os de fora do país, daí a motivação da carta. Aqui se percebe a apropriação e mobilização da ideia preexistente de uma "comunidade de destino" entre os alemães, e que permaneceu por muito tempo um Leitbild nas cidades alemãs em reconstrução após a guerra (THIEßEN, 2009, p. 171).

A referência ao passado nas demais cartas, como vimos, se refere em geral aos acontecimentos trágicos da guerra. O nazismo só é mencionado em quatro dessas cartas, mesmo assim, somente em declarações que negam qualquer envolvimento com o partido ou a ideologia. Numa das cartas, por exemplo, um remetente que pedia ao prefeito que servisse de mediador para conseguir um emprego, assim formula: "Eu sou um alemão dos Sudetos na Tchecoslováquia. Apesar de eu ser antifascista, fui expulso da Tchecoslováquia com os outros alemães e não consigo achar um emprego correspondente." ${ }^{62}$ A negação do envolvimento com o nazismo é reforçada pelo uso do prefixo "anti" e do termo depreciativo "fascista". Outro remetente da zona norteamericana assim assegurava ao final de sua carta: "Para seu conhecimento, informo ao Senhor que sou católico, bancário de profissão e politicamente totalmente não culpado (unbelastet)". ${ }^{63}$ Também duas mulheres ressaltam o seu não envolvimento com o nazismo, uma jovem da zona britânica, que afirma nunca ter sido nazista ("never nazi”) e uma professora de piano da zona soviética, que se representa como "não fascista e não partidária do nazismo". ${ }^{64}$

Tais afirmações de cunho político e moral tinham a ver com o momento político vivido, no qual se processava a "desnazificação" (Entnazifizierung) nas quatro zonas de ocupação, e que atingia membros do partido nazista que participaram mais do que nominalmente do poder ou quem tinha dado apoio ao regime. Por meio desse processo, essas pessoas deveriam ser classificadas em cinco categorias, conforme seu grau de

\footnotetext{
${ }^{62}$ Carta de Robert L. Augsburg, 14.4.1947.

${ }^{63}$ Carta de Ludwig N. München, 15.3.1947.

${ }^{64}$ Cartas de Helga P. Essen, 25.4.194[?] e Gertrud Hartmann. Jüterborg, 24.5.1947.
} 
envolvimento: (i) os acusados principais; (ii) os envolvidos, tais como ativistas, militaristas e aproveitadores do sistema; (iii) os pouco envolvidos; (iv) os seguidores; e (v) os absolvidos (BENZ, 1995, p. 69). Vale acrescentar, contudo, que, ao final do processo, os acusados, em sua maioria, foram classificados como meros "seguidores". As câmaras responsáveis pela desnazificação, que funcionavam como tribunais, acabaram servindo para anistiar e reabilitar muitos dos envolvidos. O processo, que se deu de diferentes maneiras nas quatro zonas de ocupação, durou somente até 1948, quando outros interesses diante da reconstrução e do início da Guerra Fria surgiram.

O fato de os alemães submetidos a esse processo terem tido que escrever suas trajetórias de vida e apresentá-las às câmaras responsáveis pela desnazificação, juntamente com outros documentos, é digno de nota neste artigo, principalmente se observarmos a importância dada por alguns dos remetentes à menção a um suposto passado "limpo", ou seja, sem qualquer envolvimento com o nazismo.

\section{Considerações finais}

As cartas aqui trazidas à análise são evidências de caráter testemunhal que permitem investigar como pessoas "comuns" experimentaram o pós-guerra na Alemanha. ${ }^{65}$ Elas demonstram como a experiência da Segunda Guerra Mundial se prolongou no cotidiano vivido pelos alemães, muito embora esse acontecimento histórico tivesse oficialmente terminado com a capitulação alemã, em 8 de maio de 1945.

O desafio deste artigo foi interpretar as cartas como testemunhos, sem deixar de percebê-las também como "narrativas de vítimas alemãs" da guerra. Se o que concede autoridade à testemunho, no mundo contemporâneo, é seu estatuto de vítima (HARTOG, 2011, p. 227), as narrativas das perdas, expulsões e dificuldades contidos nas cartas podem ser vistas também como uma forma de os remetentes se apresentarem ao leitor como vítimas da guerra.

\footnotetext{
${ }^{65}$ Sobre essa perspectiva historiográfica, a Erfahrungsgeschichte ("história da experiência”) alemã, vide, em português, o capítulo 5 do livro de Gertz \& Correa (2007, p. 142-172) e, mais especificamente sobre história oral e "história da experiência", vide Alberti (2005).
} 
Muito embora as cartas aqui analisadas tenham sido escritas por pessoas que escrevem a partir de suas vidas, essas cartas foram endereçadas a um órgão público/autoridade. Assim, ao saírem da esfera privada e entrarem para a pública, esses “momentos biográficos" (MALATIAN, 2011, p. 200) configurados nas cartas tornam-se testemunhos. Apesar de serem cartas de indivíduos ou de famílias, elas testemunham não somente os "destinos" pessoais e familiares, mas também de outras pessoas que são reunidas pela narrativa numa comunidade entendida enquanto Opfergemeinschaft (comunidade de vítimas) que também precisava, segundo os missivistas, de ajuda e de solidariedade da comunidade internacional. Por isso, a rememoração do III Reich não ocorre, somente a narração dos efeitos trágicos da guerra para os alemães, e não para outros grupos reconhecidos internacionalmente como vítimas da guerra. Essas cartas se apresentam, assim, como suportes para o registro de memórias e meios de afirmação da identidade individual e coletiva.

Nas memórias presentes nessas cartas, percebemos uma "nítida separação" entre o "III Reich" e a Segunda Guerra Mundial, tal como constatou Malte Thießen, ao investigar as memórias locais da guerra na Alemanha no mesmo período (2009, p. 171). Essa separação cumpria uma função muito pragmática, quando o desafio do momento, na Alemanha derrotada e em ruínas, era a reconstrução. A ideia da necessidade dessa comunhão também parece estar subjacente nos apelos feitos pelos remetentes das cartas ao prefeito e aos moradores "alemães" e "teuto-brasileiros" de Blumenau. 


\section{Referências}

ALBERTI, Verena. Fontes orais. Histórias dentro da história. In: PINSKY, Carla B. (Org.)

Fontes históricas. São Paulo: Contexto, 2005, p. 165-166.

ANDERSON, Benedict. Nação e consciência nacional. São Paulo: Ática, 1989.

ARTIÈRES, Philippe. Arquivar a própria vida. Estudos históricos, Rio de Janeiro, v. 11, n. 21, p. 9-34, 1998.

ASSMANN, Aleida. Der lange Schatten der Vergangenheit: Erinnerungskultur und Geschichtspolitik. Bonn: Bundeszentrale für politische Bildung, 2007.

BACZKO, Bronislaw. Imaginação social. In: LEACH, Edmund et al. Anthropos-homem. Lisboa: Imprensa Nacional/Casa da Moeda, 1985. p. 296-332.

BASTOS, Maria Helena C.; CUNHA, Maria Teresa S.; MIGNOT, Ana Chrystina V. (Org.) Destinos das letras: história, educação e escrita epistolar. Passo Fundo: Editora UPF, 2002.

BEDÜRFTIG, Friedemann. Lexikon Deutschland nach 1945. Hamburg: Carlsen Verlag, 1996.

BENZ, Wolfgang (Org.). Legenden, Lügen und Vorurteile: Ein Wörterbuch zur Zeitgeschichte. 7. Ed. München: DTV, 1995.

BENZ, Wolfgang (Org.).. Potsdam 1945. Besatzungsherrschaft und Neuaufbau im VierZonen- Deutschland. 3. Aufl. München: DTV, 1994.

BLAS, Verónica Sierra. "Puentes de papel”: apuntes sobre las escrituras de la emigración. Horizontes Antropológicos, Porto Alegre, ano 10, n. 22, p. 93-119, jul./dez. 2004.

CENTENÁRIO de Blumenau. Blumenau: Comissão de Festejos, 1950. p. 247.

DEMSHUK, Andrew. The Lost German East: Forced migration and the politics of memory. 1945-1970. New York: Cambridge , 2012.

DIERCKE Schulatlas für höhere Lehranstalten. 76. Auflage. Braunschweig/ Berlin/Hamburg: Verlag von Georg Westermann, [s.d.].

FERNANDES, Evandro. S.O.S Europa faminta: Comitê de Socorro à Europa Faminta - SEF. Florianópolis, 2005, 177 f. Dissertação (Mestrado em História) - Universidade Federal de Santa Catarina, Florianópolis, 2005. 
FOUCAULT, Michel. A escrita de si. In: FOUCAULT, Michel. O que é um autor? Lisboa: Passagens. 1992.

GERTZ, René Ernani; CORREA, Silvio Marcus (Org.) Historiografia alemã pós-muro: experiências e perspectivas. Passo Fundo, Santa Cruz do Sul: Ed. UPF: Ed. USCS, 2007, p. $142-172$.

GALVÃO, Walnice N.; GOTLIB, Nádia B. (Org.) Prezado senhor, prezada senhora: estudos sobre cartas. São Paulo: Cia. das Letras, 2000.

GLASER, Hermann. Deutsche Kultur: Ein historischer Überblick von 1945 bis zur Gegenwart. Bonn: Bundeszentrale für politische Bildung, 1997.

GOMES, Angela de Castro (Org.) Escrita de si, escrita da história. Rio de Janeiro: Editora FGV, 2004.

GÓMEZ, Antonio Castillo. "Como o povo e o camaleão se transformam”. Modelos e práticas epistolares na Espanha Moderna. In: BASTOS, Maria Helena C.; CUNHA, Maria Teresa S.; MIGNOT, Ana Chrystina V. (Org.) Destinos das letras: história, educação e escrita epistolar. Passo Fundo: Editora UPF, 2002, p. 13-55.

GROTHE, Hugo. Im Kamp und Urwald Südbrasiliens. Ein Skizzenbuch zur Siedlungs- und Deutschtumskunde. Halle/Berlin: Buchhandlung des Waisenhauses $\mathrm{GmbH}, 1936$.

GRUBE, Karl. Bei deutschen Brüdern im Urwald Brasiliens: Eine Rundfahrt. Leipzig: Dieterich'schen Verlagsbuchhandlung, 1916.

HAHN, Eva; HAHN, Hans Henning. Flucht und Vertreibung. In: FRANÇOIS, E.; SCHULZE, H. (Hrsg.). Deutsche Erinnerungsorte: Eine Auswahl. Bonn: Bundeszentrale für politische Bildung, 2005, p. 332-350.

HARTOG, François. Evidência da história: o que os historiadores veem. Belo Horizonte: Autêntica, 2011.

KEHL, Maria Rita. Ressentimento. São Paulo: Casa do Psicólogo, 2004.

KOSSERT, Andreas. Kalte Heimat: Die Geschichte der deutschen Vertriebenen nach 1945. 2. Edição. München: Pantheon, 2009.

LISBOA, Karen. Mundo novo, mesmo mundo: viajantes de língua alemã no Brasil (18931942). São Paulo: Hucitec/Fapesp, 2011. 
MALATIAN, Teresa. Cartas. Narrador, registro e arquivo. In: PINSKY, Carla B.; LUCA, Tania R. de (Org.) O historiador e suas fontes. São Paulo: Contexto, 2011, p. 195-221.

MORAES, Luis Edmundo de Souza. Konflikt und Anerkennung: Die Ortsgruppen der NSDAP in Blumenau und in Rio de Janeiro. Berlim, 2002, 281 f. (Doutorado em História). Technische Universität zu Berlin, Berlim, 2002.

PESAVENTO, Sandra Jatahy. Em busca de uma outra história: imaginando o imaginário. Revista Brasileira de História, São Paulo, v. 15 , n. 29, p. 9-27, 1995.

RINKE, Stefan. “Der letzte freie Kontinent": Deutsche Lateinamerikapolitik im Zeichen transnationaler Beziehungen, 1918-1933. Stuttgart: Verlag Hans-Dieter Heinz, 1996.

STEINERT, Johannes-Dieter. Migration und politik: Westdeutschland, Europa, Übersee 1945-1961. Osnabrück: Secolo-Verlag, 1995.

THIEßEN, Malte. Schöne Zeiten? Erinnerungen an die "Volksgemeinschaft" nach 1945. In: BAJOHR, F.; WILDT, M. (Org.) Volksgemeinschaft: neue forschungen zur gesellschaft des nationalsozialismus. Frankfurt: Taschen, 2009, p. 165-187.

VON PLATO, Alexander; LEH, Almut. "Ein unglaublicher Frühling": Erfahrene Geschichte im Nachkriegsdeutschland 1945-1948. Bonn: Bundeszentrale für politische Bildung, 1997.

VON PLATO, Alexander. Introdução ao Painel “Traumas na Alemanha”. In: FERREIRA, Marieta de Moraes; FERNANDES, Tania Maria; ALBERTI, Verena (Orgs.). História oral: desafios para o século XXI. Rio de Janeiro: Fundação Oswaldo Cruz/ Editora e Fundação Getulio Vargas/ CPDOC, 2000, p. 119-121.

WÜRMANN, Carsten. Der Onkel aus Amerika: The German Emigrant as a Figure of Speech and Fichtional Character. In: SCHULZE, Mathias; JOHN, David G., LIEBSCHER, Grit, SIEBELACHENBACH, Sebastian; SKIDMORE, James M. (Org.). German diasporic experiences: identity, migration, and loss. Waterloo: Wilfrid Laurier University Press, 2008, p. 281-292.

ZWANGSUMSIEDLUNG, Flucht und Vertreibung 1939-1959: Atlas zur Geschichte Ostmitteleuropas. Bonn: Bundeszentrale für politische Bildung, 2009. 
"A miséria me obriga a escrever ao senhor": a escrita de si em cartas de alemães ao prefeito de Blumenau-

Recebido em 08/03/2015 Aprovado em 26/04/2015

Universidade do Estado de Santa Catarina - UDESC

Programa de Pós-Graduação em História - PPGH

Revista Tempo e Argumento

Volume 07 - Número 15 - Ano 2015

tempoeargumento@gmail.com 